\title{
Policy Recommendations for Supporting Supply Chains with Horizontal Actions
}

\author{
Ricardo Zimmermann, Ana Cristina Barros, Pedro Pinho Senna, \\ Elena Pessot, Irene Marchiori, and Rosanna Fornasiero
}

\begin{abstract}
This chapter aims to identify the supply chain (SC) issues that can be considered "horizontal", as they are cross-sectorial and faced by most companies operating both in production and distribution sectors, and to propose a set of policy recommendations that can support public and private organisations to promote and foster innovation and competitiveness of future European SCs. The definition of the Key Horizontal Issues (KHI) is the basis for developing 12 policy recommendations regarding infrastructure requirements, technological and organisational improvements and regulatory developments needed to set the stage for the European SCs for the future. Specifically, the policy recommendations entail assuring appropriate standards and legislation for European SCs; educating and training professionals for the future SCs; drafting of international agreements aiming at future European SCs; supporting and fostering incentives and funding schemes; promoting reference bodies for European SCs; and establishing infrastructure for fostering of future European SCs.
\end{abstract}

Keywords Policy recommendations $\cdot$ Key horizontal issues $\cdot$ European supply chains

\section{Introduction}

Contemporary Europe has been experiencing unprecedented circumstances in several scopes, such as new social and consumption habits, fast development of new technologies, environmental degradation, resource depletion and climate change (Fratini

\footnotetext{
R. Zimmermann $(\bowtie) \cdot$ A. C. Barros · P. P. Senna

INESC TEC Institute for Systems and Computer Engineering, Technology and Science, Campus da FEUP, Rua Dr. Roberto Frias, 4200-465 Porto, Portugal

e-mail: ricardo.a.zimmermann@inesctec.pt

E. Pessot · I. Marchiori · R. Fornasiero

Institute of Intelligent Industrial Technologies and Systems for Advanced Manufacturing, National Council of Research (STIIMA-CNR), Via Alfonso Corti, 12, 20133 Milan, Italy e-mail: rosanna.fornasiero@stiima.cnr.it
} 
et al. 2019; Stachova et al. 2019; Szücs 2020). As a result, there is a growing demand for transformative change in how governments, companies and society as a whole tackle these challenges.

Supply chains (SCs) are complex environments that encompass a great number of actors and processes and are highly impacted by the current changes and threats (Wieland et al 2016; Calatayud et al. 2018; Zimmermann et al. 2020). In this sense, strategies for the SCs of the future have been explored in Fornasiero et al. (2020) to assure a cross-cutting approach and identify major horizontal issues to be faced also at the level of policies definition, capacities development and necessary infrastructures improvement. A Key Horizontal Issue (KHI) consists of a combination of challenges encompassing (and common to) all SC dimensions, models and strategies, and all sectors, i.e. distribution, discrete processing and manufacturing. The horizontal nature of these issues makes them especially relevant due to the potential impact they can have in a vast number of sectors and different types of SCs. Indeed, they are the core building blocks that should be addressed in a complementary manner, in order to ensure a higher value, successful and full impact on SC innovation for all research needs.

This chapter aims to identify a set of KHIs and present policy recommendations to be suggested in order to support policy maker and public organisations, such as the European Commission, Research and Technological Centres, Industrial Associations to promote and foster innovation and competitiveness of European SCs and improve the tools and the public actions to sustain the companies in facing the future challenges. Thus, the main answer addressed in this chapter is:

$R Q$. What are the main actions that the responsible public/private actors should develop in order to support European SCs to be prepared for the future challenges?

Moreover, the definition of policy recommendations is based on the core guidelines of the "Horizon Europe" framework, in order to guarantee their fit to the strategic priorities of the EU research and innovation framework programme for the next years. Horizon Europe builds around the vision of "a sustainable, fair and prosperous future for people and planet based on European values" and is aligned with the 17 sustainable development goals proposed by the United Nations (European Commission 2018a).

The application of supply chain management (SCM) insights to policy debates could present notable benefits to both the public and private sectors, and vastly increase the awareness of the significance of SCM field among practitioners and legislators. SCM researchers should give more attention to policy research as this field is specially well positioned to communicate with public decision makers as both, policy making and SCM, are built on the focus on interdependencies and processes using a systems perspective (Tokar and Swink 2019). Although SCM researchers have the unique capability to make important contributions to policy research in a variety of areas, they have given little attention to public policy implications of their work. Tokar and Swink (2019) call for SCM researchers to expand the full network of actors in their research to include government and nongovernment organisations. Given the rapidly changing geopolitical and regulatory environments that influence 
and sometimes disrupt SCM around the world, the policy area represents a rich opportunity for study, offering the potential for contributions that can affect practice in different ways than conventional SCM research. Research should seek to understand and investigate the unique SCM and public policy characteristics, explore comparative studies across countries, and/or identify more generalizable timely solutions at the intersection of SCM and public policy (Fugate et al. 2019).

The remaining sections of this chapter are structured as follows. The methodology used is presented in Sect. 2. Section 3 describes the key horizontal issues, while Sect. 4 presents a set of policy recommendations. Finally, the main conclusions of the chapter are discussed in Sect. 5.

\section{Methodology}

The identification of the KHIs and the development of policy recommendations entailed an extensive data collection. Multiple sources of data were selected, including primary and secondary sources. Primary data were collected by means of the consultation of experts and the workshops organised in Brussels, Zaragoza and Porto in the first semester of 2019 involving more than 100 experts from industry, research organisations and governmental bodies. Data and opinions collected from these sources were integrated with the results from the review of roadmaps, research agendas and reports on the specific topics (i.e. KHIs and their implications at SC level), and other relevant documentation from federations, national platforms, clusters, European Commission and other reference organisations.

Expert elicitation was applied following the guidelines proposed by Morgan (2017). This approach allowed to keep the KHIs at SC level as the experts were able to easily shift from a pure research-based approach to the definition of a policy need on the specific themes they highlighted. Secondly, the integration between the issues identified by the experts participating to the consultation and the KHIs identified in the secondary sources allowed to further enhance the validity of the results.

In the first phase of data analysis, the KHIs were identified as the issues requiring cross-cutting approaches and interventions by organisations and decision makers at regional, national and European level, and that cannot be (or require a significant effort to be) directly influenced by single companies or SCs. Specifically, the analysis of the first list of horizontal issues was performed by defining codes (i.e. classes) of issues that were qualitatively different at macro level. Subsequently, the sources collected were further reviewed to identify the sub-issues, i.e. the micro-level issues, as the possible areas of intervention for each KHI (or macro-level issues) that had specific impacts on the single company or in the single SC or influenced by their actions.

The second phase of data collection and analysis was aimed at formulating a series of policy recommendations for each KHI. A preliminary important step towards the development of policy recommendations is the early identification of the target audience-which is the public to whom the document is intended to be delivered and is 


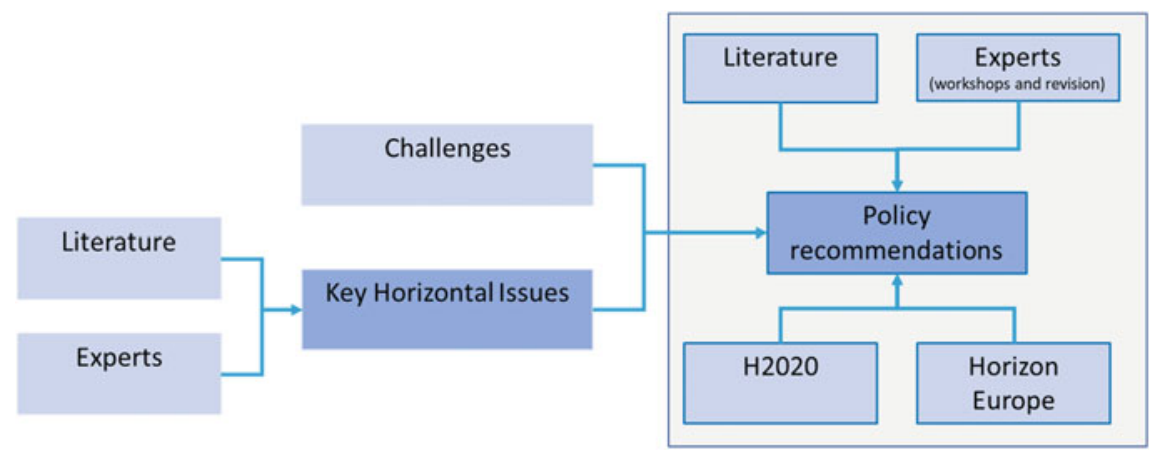

Fig. 1 Methodology for the development of the policy recommendations

expected to act upon it-in order to guarantee the use of the appropriate tone and terminology. In this work, the primary target audience is European Commission, as well as institutions that usually inform the European Commission, such as Research and Technological Centres, Public Privacy Partnerships, and Industrial Associations. Beyond the sources of data for the KHI identification, the recommendations were developed by mean of literature review and collaboration of experts. Experts were involved in two stages: (1) during the participation in a workshop, and (2) in the review of the policy recommendations. The workshop took place in Porto and participants discussed the KHIs in groups and suggested actions to be considered in the development of the policy recommendations. In order to validate the results of the literature review and of the workshop, other experts, with expertise in the identification of recommendations for public bodies, were then invited to contribute in the process of revision, aiming to enhance the reliability of the research. A total of 12 policy recommendations were identified. Figure 1 shows the methodology used to develop the policy recommendations.

The recommendations presented in this chapter may come in the form of: (1) a policy, understood as a set of ideas or plans that is used as a basis for making decisions, and represents a long-term commitment; (2) a project, which is a temporary effort with the purpose to create a specific solution; or (3) a programme, which can be defined as a set of related projects managed in a coordinated way in order to obtain broader benefits. The recommendations may also demand new mechanisms or instruments specifically for the European Commission.

The structure used for drafting the recommendations portrayed on this chapter follows the works of Morgan (2017), Doyle (2017) and Copeland (2017), as well as the structure used by OECD (2019). It comprises of a series of actions to be addressed, interlinked through a concise and well-established framework that aims at providing meaningful and summarized description of the selected recommendations. 


\section{Key Horizontal Issues}

The horizontal issues presented below emerged from the analysis of both primary (i.e. the consultation of experts and workshops) and secondary sources (i.e. literature review).

The KHIs consist of a set of transversal topics that affect all the SC dimensions and strategies, and are related to all industrial sectors (in this work, discrete manufacturing, process industry and logistics and distribution are considered). The set of KHIs identified is: (1) Standardization; (2) Regulatory framework; (3) Training and education for skills gaps; (4) International agreements; (5) Incentives and funding schemes; (6) Reference bodies for European SCs; and (7) Infrastructure.

The first KHI refers to the lack of standards for the management of the SC processes and the difficulties for companies to implement standards, as the legislation between European countries has not been harmonized yet. Moreover, independent associations and standardization bodies do not consider dissemination activities and this represents another obstacle for the full implementation of the already existing standards and regulations. Standardization refers to the implementation and development of technical standards based on consensus of different parties (firms, consumers, interest groups, standards organisations and governments), concerning aspects with a direct impact on SC dimensions and performance that require the setting of common conditions and characteristics. Standards are important since they are aimed at covering "grey zones", establishing commonalities and enhancing better interconnections between SC tiers but at the same time, it is important that standards don't slow down innovation for all SC actors and in all SC dimensions.

As for standards, there is also a lack of harmonization at local, national and European levels of regulatory frameworks defined as the compendium of information and procedures on tax, customs, required regulations, relevant rules, abiding laws (or new). This KHI has arisen from the identification of a lack of legislation on specific issues with a direct impact on SC dimensions and performance. Europeanwide harmonization or reinforcements of legislations and normative systems of rules on SC issues are required at local, regional and European levels, as well as specific legislations at these levels. Legislations should be neutral to technology, avoid dumping strategies, and push innovation capacity of all SC actors. Different bodies should promote new regulatory frameworks also through the collaboration with SC professionals.

Training and education skills gaps refers to the necessity of identify the new skills, as well as hard and soft competences, required to the workers by the implementation of new technologies and SC strategies. There is also the need to enhance the workers' safety and well-being in SC operations.

The KHI on international agreements is related to the lack of a systemic perspective on the overall SC in the existing agreements and therefore companies are still facing barriers in dealing with the terms and conditions in different areas of their operations. Moreover, it is necessary to foster participation, joint efforts (and actions) and 
collaboration between the European non-European countries not only for business reasons but also for research, innovation in the SC field.

Considering the initiatives already proposed in the European work programmes other incentives and funding schemes, which include measures and supporting instruments aimed at encouraging demonstrations (i.e. developing business cases) and pilot-tests are needed. Digital technologies have to be tested in safe environments and in real contexts and, as well as their large-scale applications; capacity building by leveraging on entities such as the Digital Innovation Hubs and promoting training vouchers should be managed at regional, national and European levels.

The KHI on reference bodies for European SCs entails the need for specific bodies, internationally recognized, to deal with topics like defining, deploying and measuring standards on SC, promoting standardized performance indicators models and monitoring system to collect data on European SCs' practices, strategies and instruments.

Finally, infrastructure refers to the lack of integrated and secured communication infrastructure with efficient and real-time data exchange, visibility, advanced and secure data management along SCs. Moreover, it encompasses the requirement for smart (green) energy infrastructure and services, and investments in logistics infrastructure to move goods all over European territory, to prioritize maintenance equipment, to promote flexible integration between freight and people transportation to avoid congestion in urban areas.

\section{Policy Recommendations}

This section displays the policy recommendations that derive from the KHIs and can be grouped in the following macro-areas:

- Assuring appropriate standards and legislation for European SCs;

- Educating and training professionals for the future SCs;

- Drafting of international agreements aiming at future European SCs;

- Supporting and fostering incentives and funding schemes;

- Promoting reference bodies for European SCs;

- Establishing infrastructure for fostering of future European SCs.

The KHIs standardization and regulatory framework are both addressed in first macro-area, with the related policy recommendations. 


\subsection{Assuring Appropriate Standards and Legislation for European SCs}

Despite the continuous efforts carried out by different Governments across Europe, the lack of harmonised legislation and standards among countries is still a concern and generates logistics and administrative burdens/costs. Thus, there is a need to foster the harmonisation of legislation and standards on SC related aspects in order to simplify procedures for businesses and customers as much as possible.

Due to their collaborative and global nature (Zimmermann et al. 2019), SCs are highly impacted by differences in regulations. When it comes to the free movement of products across Europe, industry sectors can be divided into two groups (European Commission 2019a): harmonised sectors and non-harmonised sectors. Harmonised sectors are subject to common rules, which provide a clear and predictable legal framework for businesses. If manufacturers follow these rules, their products can be sold freely in the market. In the majority of sectors (e.g. electronic and electric equipment, machinery, lifts, medical devices), however, EU legislation is limited to essential health, safety, and environmental protection requirements. In other sectors, such as automotive and chemicals, legislation provides more detailed requirements obliging certain types of products to have the same technical specifications. Nonharmonised sectors are not subject to common EU regulation and the national rules are subject to a notification procedure that ensures they do not create undue barriers to trade (European Commission 2019a). Approximately half of the trade in goods within the EU is covered by harmonised regulations, while the other half is accounted for by the non-harmonised sectors (CECE 2019).

In terms of standards, the European Committee for Standardization (CEN) has established agreements with the International Organization for Standardization (ISO, Vienna Agreement) and the International Electrotechnical Commission (IEC, Frankfurt Agreement) aimed at promoting harmonization of standards on the international level. Thus, the intent is to provide benefits of the international standards to international trade and markets harmonisation, with high level of convergence between the European and international standards. This occurs through a framework for optimal use of resources and expertise available on standardization procedure, and through a mechanism of information sharing between internal and European Standardization Organizations (ESOs) with intent to increase the transparency of ongoing work at international and European levels (European Commission 2019c).

Standards are considered vital tools for enabling the adoption of technologies and innovations, especially when considering the industrial scenario. Their everincreasing drafting and establishment by numerous standard bodies have contributed to the improvements seen in safety, security, agility and quality of operations, of componentry development, and of organisations. Nevertheless, this same aspect of the standardization effort is currently considered a disadvantage for companies, since it makes difficult for the seamless integration and interoperability required in the digital industrial and logistics environments (Lu et al. 2016). 
Finally, particular attention has to be given to standards and legislations related to logistics topics for the development of a common transports policy. According to the European Environment Agency (EEA 2019a), transports account for around a third of all final energy consumption, for more than a fifth of greenhouse gas emissions and are also responsible for a large share of urban air and noise pollution. In this sense, the creation of regulatory conditions to foster greener transport alternatives is required and regulation and standards on the use of multimodal transportation is especially relevant. Multimodal transports' share among the total number goods transportation is still very low (European Commission 2018b) and more actions and programs are needed. Nowadays, differences in technical equipment, infrastructural facilities available and administrative and public structures, regulation and standards are the major obstacles to comprehensive multimodal transportation management within and beyond EU borders. Moreover, the incentive to multimodality presupposes the incentive to a balanced set of investments in infrastructure of all the transport means. In the last decades, due to incentive policies and private investments, roads as means of transport have been developing in a faster pace when compared to other modes. Short sea shipping has also been fostered in the last years by the EC, presenting a growing relevance in terms of gross weight of goods all around Europe (Eurostat 2019). However, the adoption of multimodal transports relies on a balanced set of options, including (and highlighting) rail, an efficient and sustainable option, particularly when combined with other modes. In transportation systems, the rail freight is usually cheaper than the road freight as train can carry larger volumes over longer distances. In addition, railroad transports are four times more fuel efficient than road transportation. On the other hand, rail transports are characterised by a certain lack of flexibility, as routes and times usually cannot be adjusted. Road transportation tends to be more expensive but offers flexibility in terms of final destination and volume of goods to be transported.

Table 1 presents the three policy recommendations proposed on the topic of regulation and standards.

\subsection{Educating and Training Professionals for the Future SCs}

According to the American Production and Inventory Control Society (APICS), the industry leader in SC certification, training and networking, and now part of the Association for Supply Chain Management (ASCM):

Supply chain managers are crucial to the global economy. They represent a unique discipline responsible for supporting the global network of delivering products and services across the entire supply chain, from raw materials to end customers. Specifically, supply chain managers engage in the design, planning, execution, control, and supervision of supply chain activities with the objectives of creating net value, building a competitive infrastructure, leveraging worldwide logistics, synchronizing supply with demand, and measuring performance globally (APICS 2019). 
SC requires a wide range of multidisciplinary skills to ensure its correct management in the industry and the company competitively. In this sense, an exhaustive identification of the competencies required for the professionals in SC is crucial. With an ever-evolving technological and economic landscape, the SC education and professional development experts need to work together to identify the competencies that every workers (managers, technicians and specialized operators) should reflect. This requires close collaboration with the industry to ensure that the mapping of

Table 1 Policy recommendations on regulation and standardization

\begin{tabular}{|c|c|c|}
\hline Policy recommendation & Main issue & What should policy makers do? \\
\hline $\begin{array}{l}\text { Fostering harmonisation of } \\
\text { legislation and standards on } \\
\text { European SCs }\end{array}$ & $\begin{array}{l}\text { Different legislation among EU } \\
\text { countries in SC related aspects } \\
\text { generates costs and harms } \\
\text { transparency of transactions, } \\
\text { both for companies and end } \\
\text { consumers }\end{array}$ & $\begin{array}{l}\text { - Stimulate a continuous effort } \\
\text { toward the harmonisation of } \\
\text { SC regulations and standards } \\
\text { - Simplify procedures for } \\
\text { businesses and customers } \\
\text { - Facilitate the access to } \\
\text { information regarding } \\
\text { regulation and standards } \\
\text { - Create work groups (with a } \\
\text { broad coverage in terms of } \\
\text { countries, industry sectors } \\
\text { and company sizes) aimed at } \\
\text { promoting the continuous } \\
\text { convergence and adaptation } \\
\text { of legislation and norms } \\
\text { - Encourage harmonisation } \\
\text { effort towards } \\
\text { standardization of enabling } \\
\text { technologies used within } \\
\text { European SCs }\end{array}$ \\
\hline $\begin{array}{l}\text { Disseminating standards } \\
\text { among EU SC stakeholders }\end{array}$ & $\begin{array}{l}\text { Current and former activities } \\
\text { developed in the context of } \\
\text { European Research programs } \\
\text { or by independent associations } \\
\text { and standardization bodies do } \\
\text { not consider dissemination } \\
\text { activities }\end{array}$ & $\begin{array}{l}\text { - Promote sensible } \\
\text { dissemination of knowledge } \\
\text { on the use of, contributions } \\
\text { to, and development of } \\
\text { standards that are commonly } \\
\text { used in SC-related activities } \\
\text { - The dissemination activity } \\
\text { can occur through the Digital } \\
\text { Innovation Hubs initiative } \\
\text { and through the European } \\
\text { Logistics Association, as well } \\
\text { as other European } \\
\text { associations } \\
\text { The communication of } \\
\text { standards can be included in } \\
\text { the new Horizon Europe } \\
\text { program as a requirement for } \\
\text { call proposals }\end{array}$ \\
\hline
\end{tabular}


Table 1 (continued)

\begin{tabular}{|c|c|c|}
\hline Policy recommendation & Main issue & What should policy makers do? \\
\hline $\begin{array}{l}\text { Facilitating and boosting } \\
\text { multimodal transportation }\end{array}$ & $\begin{array}{l}\text { Imbalance in the use of } \\
\text { different transport modes (air, } \\
\text { inland waterway, rail, road and } \\
\text { maritime). Lack of incentives } \\
\text { to the use of multimodality }\end{array}$ & $\begin{array}{l}\text { Development of legislation } \\
\text { and policies which facilitate } \\
\text { and stimulate the } \\
\text { implementation of } \\
\text { multimodal transportation } \\
\text { - Foster a broad discussion on } \\
\text { the Combined Transport } \\
\text { Directive (Council Directive } \\
\text { 92/106/EEC of } 7 \text { December } \\
\text { 1992) resulting in a wide } \\
\text { update of or the creation of a } \\
\text { new directive } \\
\text { Ensure the protection of } \\
\text { companies and consumers } \\
\text { rights in multimodal } \\
\text { transportation } \\
\text { - Create mechanism to } \\
\text { guarantee the traceability of } \\
\text { loads in the context of } \\
\text { multimodal transportation } \\
\text { Minimise the imbalance in } \\
\text { terms of documentation and } \\
\text { customs control in the mode } \\
\text { change points in order to } \\
\text { make the changes faster and } \\
\text { smoother (especially in } \\
\text { seaports) }\end{array}$ \\
\hline
\end{tabular}

competencies reflects the reality of the needs in SC training demanded by the companies. Due to the growing relevance of topics such as a broader understanding and application of sustainability issues, emergence of new technologies, digitalization and a fundamental review of processes, SCM is going through a deep transformation (Min et al. 2019). This transformation requires the continuous alignment of the competencies of the SC workforce with the new requirements, in order to provide the companies with SC professionals that meet their needs. For example, with the intensification of the personalized requirements, it becomes essential for managers to develop capabilities as creativity and critical thinking to sense shifting patterns in customer preferences and subsequent demand changes and to respond to the customers ever more demanding and sophisticated requirements at a nearly individual level. Another example comes from the adoption of new technologies such as the additive manufacturing: workers has to be able to use the new $3 \mathrm{D}$ printers and also managers have to develop skills as decision making to face the structural changes of the SC and be able to manage new relationships since there will be just three major participants (a focal firm, its immediate supplier, and customer) (Ben-Ner and Siemsen 2017). 
Table 2 Overview of the skills and competences identified for the SCs of the future

\begin{tabular}{l|l}
\hline Category & Skills/competences \\
\hline Personal skills & $\begin{array}{l}\text { Decision making, analytical skills, leadership, teamwork, creativity, learning } \\
\text { ability, critical thinking, change management, conflict resolution, } \\
\text { communication skills, cultural awareness/global citizen, holistic SC thinking, } \\
\text { consultancy skills, management of diversified KPIs, corporate governance, } \\
\text { costs management, evaluate offers \& supplier selection, forecasting of the } \\
\text { demand, intellectual property, quality management, risk management }\end{array}$ \\
\hline Technology & $\begin{array}{l}\text { Data analytics, human-machine interaction, automation (PSM technology), } \\
\text { Enterprise Resource Planning/material requirements, procurement IT } \\
\text { systems, e-procurement technology, remote virtual working, technology } \\
\text { planning, openness to new technologies }\end{array}$ \\
\hline SC configuration & $\begin{array}{l}\text { Principles of circular economy, closed loop SCs, knowledge about carbon } \\
\text { footprints, green production, green logistics, green sourcing, green } \\
\text { packaging, green accounting exposure to quantitative techniques }\end{array}$ \\
$\begin{array}{l}\text { Coexistence of lean (or efficient) and agile (or responsive) SC features, new } \\
\text { ways of SC partnering and contracting, Exclude, global sourcing/supplier } \\
\text { acquisition, early supplier involvement, innovative sourcing approaches, } \\
\text { collaborative innovation processes, new business models as a consequence of } \\
\text { new technologies, coexistence of large-scale SC structure for mass } \\
\text { customization and small-scale home-based SCs for customization and } \\
\text { personalization }\end{array}$ \\
\hline
\end{tabular}

An overview of the skills and competences required for the workforce of the SCs of the future are compiled in Table 2.

Table 3 presents the policy recommendation on education and training.

\subsection{Drafting of International Agreements Aiming at Future European SCs}

International agreements are formal understandings or commitments between two or more countries. According to international law, a treaty is a legally binding agreement between states and can be made in the format of conventions, protocols, pacts, accords, etc., which relates to the content of the agreement (Raustiala 2005). There are several international agreements that entail specific topics which can be considered as core for the structuring and management of SCs, e.g. trade, transport infrastructures, or environment (i.e. energy efficiency and sustainability). European companies are still facing barriers and difficulties in dealing with them in their operations, especially when they are on a global base. Moreover, these agreements still lack a holistic perspective on the overall SCs and need to be updated in order to face the major changes of European (and global) SCs in front of trends such as digitalization, servitization and urban production. A first attempt is the one carried out by Nakatomi (2012) who promoted an "International Supply Chain Agreement (ISCA)" 
Table 3 Policy recommendations on education and training

\begin{tabular}{|c|c|c|}
\hline Policy recommendation & Main issue & What should policy makers do? \\
\hline $\begin{array}{l}\text { Developing the workforce for } \\
\text { the SCs of the future }\end{array}$ & $\begin{array}{l}\text { Shortage of skilled SC } \\
\text { professionals across European } \\
\text { countries. Gap between } \\
\text { companies' requirements and } \\
\text { the competences provided by } \\
\text { education and training } \\
\text { institutions. Current education } \\
\text { and training programs usually } \\
\text { do not sufficiently consider a } \\
\text { set of relevant topics }\end{array}$ & $\begin{array}{l}\text { - Evaluating available } \\
\text { programs and promoting the } \\
\text { reconversion of obsolete } \\
\text { profiles, including new } \\
\text { competences and skills } \\
\text { demanded by the industry } \\
\text { - Support and train companies } \\
\text { to be able to map } \\
\text { competences and detect the } \\
\text { existing gaps of their SC } \\
\text { professionals and foresee } \\
\text { future needs } \\
\text { - Dissemination of the new } \\
\text { trends and tendencies in SC } \\
\text { to allow the companies to be } \\
\text { ready and train their } \\
\text { professionals in advance } \\
\text { - Promoting the creation } \\
\text { and/or the adoption of a } \\
\text { European SC professionals' } \\
\text { certification and } \\
\text { standardization } \\
\text { - Incentivize training through } \\
\text { tax incentives, subsidies, and } \\
\text { individual credits } \\
\text { - Support the use of current } \\
\text { and future European funding } \\
\text { programmes in the area of } \\
\text { skills development } \\
\text { (Erasmus+, Blueprint) }\end{array}$ \\
\hline
\end{tabular}

for global SCs, but mainly focused on trade issues. A key reference are also the calls for proposals already launched by the European Commission in the Horizon 2020 framework that deal with SC-related topics, or could have a relevance for the SC dimensions and practices. In this sense, European Commission should foster the widening of the scope these calls in order to consider an overall SC perspective.

Focusing on research priorities, the efficacy and sustainability of the Strategic Research Agenda for the future European SCs requires entering bi- and multilateral agreements that are aimed at promoting the continuous research, dissemination and education on the research and innovation priorities defined at the whole SC level. These agreements should be aimed also at the establishment of research and innovation networks, collaborating to enhance advancements, innovations and dissemination of topics that bear an overall SC perspective. Such agreements would occur through cooperation and partnerships between EU and non-EU research and education institutions. 
A systematic framework fostering the creation of international agreements could take as example from existing experiences (e.g. the MIT global network with branches all over the world), but as a European-based initiative. Agreements should enable the creation of networks and institutions delivering SC-targeted activities including entrepreneurship, research projects on the strategic research agenda topics and training on use of enabling technologies. They should leverage existing facilities and initiatives, e.g. network of Digital Innovation Hubs (DIH), to be extended at biand multi-lateral agreements also with third countries. Moreover, there is the need of SC-focused agreements to encompass several topic areas, i.e. scientific (e.g. environmental and energy-related issues), managerial (e.g. SC management), industrial (e.g. issues concerning SCs of a specific sector) and policy-related (e.g. international relations). Table 4 summarises the policy recommendations on international agreements.

Table 4 Policy recommendations on international agreements

\begin{tabular}{|c|c|c|}
\hline Policy recommendation & Main issue & What should policy makers do? \\
\hline $\begin{array}{l}\text { Promoting bi- and } \\
\text { multi-lateral agreements with } \\
\text { an overall SC perspective }\end{array}$ & $\begin{array}{l}\text { Due to the lack of a systemic } \\
\text { perspective on the overall SC } \\
\text { in the existing agreements, } \\
\text { companies are still facing } \\
\text { barriers in dealing with the } \\
\text { terms and conditions in } \\
\text { different areas of their } \\
\text { operations }\end{array}$ & $\begin{array}{l}\text { - Systematization of analyses } \\
\text { and identification of gaps } \\
\text { between existing agreements } \\
\text { and necessities on SC-related } \\
\text { topics } \\
\text { - Create a panel of experts } \\
\text { from industrial, scientific and } \\
\text { legal environments, managed } \\
\text { by the European Commission } \\
\text { and promoted by all EU } \\
\text { countries } \\
\text { - Define priorities of } \\
\text { intervention for international } \\
\text { agreements that address SC } \\
\text { dimensions, actors and } \\
\text { strategies } \\
\text { Identify and implement } \\
\text { initiatives to support bi- and } \\
\text { multi-lateral collaboration } \\
\text { between EU and non } \\
\text { EU-countries on identified } \\
\text { priorities } \\
\text { - Promote the launch of calls } \\
\text { for proposals aimed at } \\
\text { international cooperation and } \\
\text { bureaucratic simplification, } \\
\text { and involving more European } \\
\text { Commission Directorates }\end{array}$ \\
\hline
\end{tabular}


Table 4 (continued)

\begin{tabular}{|c|c|c|}
\hline Policy recommendation & Main issue & What should policy makers do? \\
\hline $\begin{array}{l}\text { Supporting the establishment } \\
\text { of R\&D networks for } \\
\text { advancements and } \\
\text { dissemination of SC-related } \\
\text { topics }\end{array}$ & $\begin{array}{l}\text { With the growing globalized } \\
\text { SCs, international agreement } \\
\text { are needed to improve } \\
\text { collaboration with research } \\
\text { and education institutions } \\
\text { outside European boundaries }\end{array}$ & $\begin{array}{l}\text { - Enter international } \\
\text { agreements aimed at the } \\
\text { establishment of research and } \\
\text { innovation networks focused } \\
\text { on SC-related topics } \\
\text { - Foster cooperation and } \\
\text { partnerships between EU and } \\
\text { non-EU research and } \\
\text { education institutions to } \\
\text { leverage on commonalities } \\
\text { and peculiarities in industry- } \\
\text { and research-related issues } \\
\text { - Allocate financial resources } \\
\text { or find new opportunities for } \\
\text { innovation or exploitation of } \\
\text { existing facilities and } \\
\text { initiatives } \\
\text { - Networks should be } \\
\text { co-created by Higher } \\
\text { Education Institutions, } \\
\text { Member States and the } \\
\text { European Commission and } \\
\text { encompass several research } \\
\text { areas that deal with } \\
\text { SC-related topics } \\
\text { - Stimulate the creation of } \\
\text { networks and institutions } \\
\text { delivering SC-targeted } \\
\text { activities } \\
\text { Monitor cooperation } \\
\text { activities sustained by the } \\
\text { agreements }\end{array}$ \\
\hline
\end{tabular}

\subsection{Supporting and Fostering Incentives and Funding Schemes}

Incentives and funding schemes are comprised of support actions that encourage demonstrations and pilot-tests of technologies in safe environments and real contexts, as well as their large-scale applications. Also, there is lack of common definition of SC best practices characterized by a set of KPIs, as well as their sharing and implementation among European companies and the need for better funding that combines efforts from public and private sectors is required for fostering faster and greater improvement of SC activities at European level.

The European Framework Programme for Research and Technological Development is at the ninth edition with Horizon Europe (FP9). Since its adoption in 1984, the budget allocated have significantly increased until today and have supported great 
results and technological breakthroughs (European Ccommission 2018a). Through this Research and Development policy, the European Commission aims to promote the collaboration of the different academic and industrial parties to foster the European strengths and to develop strategic technologies. Based on the principles of open innovation and trustful collaboration between different countries, the European Commission looks to encourage and support growth, job creation and adaptation to the digital transformation. Since the first program, the budget allocated has increased from 3.8 billion $€$ to 77 billion $€$ (European Commission 2018a).

However, it appears that, due to a lack of follow-up, some of the outcomes and results from strategic European projects were "lost" and not fully exploited after their conclusions. Most of the time required to ensure that a viable commercial product or service is reached comes after the project closure, through steps that are not usually defined as part of the project proposal procedure. A systematic follow-up of project outcomes that ensure the full and complete exploitation of project results after its completion is a real need. There is a need for fostering effective collaboration with established and future projects, thus ensuring projects' continuity, especially on SC-related topics.

Moreover, a lot of improvements could be achieved by defining and adopting best practices for SCM, considered one of the critical areas throughout Europe, and encompassing many technologies. For example, a common framework is missing to establish common practices and language, to be applied to the different sectors where $\mathrm{SC}$ is of first importance. Differences in work culture from one country to another, from one type of industry to another, could be leveraged and integrated to define different configurations of SCs. The adoption of best practices regarding common goals across Europe would lead to a faster, more reliable and more efficient achievement of competitive advantages and sustainable development goals. For instance, SCs have significant carbon footprint, which could be mitigated through establishment of common mechanisms in the different European industrial sectors, thus, greatly contributing for the European goal to fulfil the Paris Agreement and diminish the environmental impact of SCs.

Moreover, the definition of KPIs related to the SC is an important step to recognize and acknowledge best practices to be included in a common framework throughout European industrial landscape. KPIs would also enable prioritizations of some particular aspects, such as sustainability, circular economy and carbon footprint. These should be properly defined, adopted and disseminated by different stakeholders, including private partners and public organisations, which are necessary to bridge the gap in the SC practices and to further integrate research developments and industry priorities. Bearing this context, the creation of a network structure is required for fostering innovative, risk-tolerant, and flexible financing mechanism as well as inclusive market development approaches within EU. These initiatives would address the financing gap in SC transformation through innovation, i.e. affecting the on-time implementation of industrial and societal programmatic priorities of the new Horizon Europe.

A key aspect to take into account is that conducting technology-risky projects with great business potential could either lead to game changing services or processes, or to 
(temporary) failures. Therefore, the financial risks should be shared between public sectors (who will benefit indirectly from high potential outcomes) and industries (who will benefit directly from them). The creation of Venture Capital led by both public and private sectors would help to create synergies to deliver the next game changer innovations. Table 5 presents three policy recommendations on supporting and fostering incentives and funding schemes.

Table 5 Policy recommendations on supporting and fostering incentives and funding schemes

\begin{tabular}{|c|c|c|}
\hline Policy recommendation & Main issue & $\begin{array}{l}\text { What should policy makers } \\
\text { do? }\end{array}$ \\
\hline $\begin{array}{l}\text { Enhancing collaboration } \\
\text { based on European Projects } \\
\text { results }\end{array}$ & $\begin{array}{l}\text { Effective collaboration with } \\
\text { future projects, established } \\
\text { networks and SC industry is } \\
\text { crucial for a project to create a } \\
\text { follow-up of the outcomes. } \\
\text { Current lack of visibility of the } \\
\text { project results and lack of } \\
\text { collaboration through different } \\
\text { segments. Need to further } \\
\text { support funding for large-scale } \\
\text { projects (TRL } 7 \text { and above) }\end{array}$ & $\begin{array}{l}\text { - Identify and evaluate the } \\
\text { existing collaboration } \\
\text { mechanisms to ensure the } \\
\text { application and continuity of } \\
\text { the results and knowledge } \\
\text { generated by European } \\
\text { projects and programs } \\
\text { - Encourage funding of } \\
\text { pilot-test and large-scale } \\
\text { applications of outputs and } \\
\text { results of previous European } \\
\text { projects } \\
\text { - Address as main objective of } \\
\text { the collaboration after the } \\
\text { project completion the } \\
\text { visibility, communication } \\
\text { and transfer of the project } \\
\text { results as a benefit to new } \\
\text { initiatives in the SC sector }\end{array}$ \\
\hline $\begin{array}{l}\text { Establishing a prize to support } \\
\text { and spread best practices in } \\
\text { the SC }\end{array}$ & $\begin{array}{l}\text { There is no common definition } \\
\text { of the best practices in the SC } \\
\text { areas for all stakeholders } \\
\text { involved, inhibiting the } \\
\text { proposition of KPIs. Sharing } \\
\text { and implementation of SC best } \\
\text { practices in European } \\
\text { industrial landscape is scarce } \\
\text { and seldom. There is the need } \\
\text { to incentivize the adoption of } \\
\text { best practices }\end{array}$ & $\begin{array}{l}\text { - Creation of a prize for the } \\
\text { development and } \\
\text { dissemination of best } \\
\text { practices, involving all } \\
\text { member of the SC } \\
\text { - Define accurate KPIs that } \\
\text { will be used as a reference } \\
\text { throughout Europe } \\
\text { - Define best practices for the } \\
\text { European SCs, following } \\
\text { with the KPIs aimed at } \\
\text { enhancing SC efficiency and } \\
\text { sustainability } \\
\text { - Ensure the communication } \\
\text { tools to disseminate the } \\
\text { knowledge and to apply } \\
\text { these best practices into } \\
\text { other sectors and } \\
\text { other organisations }\end{array}$ \\
\hline
\end{tabular}


Table 5 (continued)

\begin{tabular}{l|l|l}
\hline Policy recommendation & Main issue & $\begin{array}{l}\text { What should policy makers } \\
\text { do? }\end{array}$ \\
\hline $\begin{array}{l}\text { Creating synergies between } \\
\text { public and private sectors in } \\
\text { funding }\end{array}$ & $\begin{array}{l}\text { SC partners are usually not } \\
\text { involved in the definition of } \\
\text { priorities of the OEMs, be it } \\
\text { from the public sector } \\
\text { (government branches and } \\
\text { industrial associations) and the } \\
\text { private sector (suppliers and } \\
\text { distributors) }\end{array}$ & $\begin{array}{l}\text { Setting up a stakeholder } \\
\text { engagement and partnership } \\
\text { structure in order to gather } \\
\text { European catalytic funding } \\
\text { consortium } \\
\text { Focusing on the } \\
\text { (M)SME-intensive EU } \\
\text { regions lacking access to } \\
\text { innovation financing } \\
\text { instruments and prioritize } \\
\text { the candidates from those } \\
\text { regions } \\
\text { Developing transparent } \\
\text { selection criteria of } \\
\text { evaluation requirements, } \\
\text { expert judges, and } \\
\text { internal/external reporting } \\
\text { structures on the evaluation } \\
\text { process }\end{array}$ \\
& & \\
& & \\
&
\end{tabular}

\subsection{Promoting Reference Bodies for European SCs}

Considering the complexity and broad character of the European SCs, as well as the consequent dispersion of information about main features, trends and research advances related to SC, as well as best practices, use cases in Europe appear to be difficult to be gathered in an organic and systematic way. The analysis of the existing European bodies like observatories and associations has highlighted that these initiatives aim to promote networking and dissemination activities on some specific topics and most of them have an active role in the definition of new roadmaps while also monitoring the evolution of practices and technologies. However, these bodies focus on some specific sub-topics and sub-sectors of the European networks and they do not allow to create a comprehensive vision of the status of SCs in Europe. This is also linked to the decentralization of economic data in many different databases and missing tools to aggregate data in order to create a picture of the networks at macrolevel to map where the SCs are located, how the flows are handled and which are the best practices. There is lack of KPIs to measure the most important features of SCs (e.g. operational efficiency, process reliability, responsiveness, capacity utilization, sustainability), to compare SCs of the same sector or more widely of different sectors, to measure the impact of the SC at macro-economic level and the weight of added-value of different sub-activities along the networks.

For these reasons, the development and establishment of a European SC observatory is recommended. This body should integrate different approaches becoming a reference in the study and development of a strategic vision for the future SCs for 
industrial stakeholders, academics and policy makers A knowledge hub is a platform which aims to facilitate the access to data, information and knowledge, as well as stimulate the exchange and the creation of a network around a certain topic. Some of the main advantages of the development of this kind of platform are: the access and understanding, the availability of data and information timely and in a simple format, the accessibility to all stakeholders, geographically dispersed and with different education and background. Table 6 presents the main characteristics of the recommendation on reference bodies.

Table 6 Policy recommendations on reference bodies

\begin{tabular}{|c|c|c|}
\hline Policy recommendation & Main issue & What should policy makers do? \\
\hline $\begin{array}{l}\text { Creating a European SC } \\
\text { observatory }\end{array}$ & $\begin{array}{l}\text { Much of the existing information } \\
\text { and knowledge regarding SCs in } \\
\text { Europe are difficult to find and } \\
\text { access. There is a lack of } \\
\text { dissemination and a clear } \\
\text { underutilisation of good/best } \\
\text { practices in SCs and of the } \\
\text { results of the research projects }\end{array}$ & $\begin{array}{l}\text { Develop and establish an open } \\
\text { data SC observatory, which } \\
\text { will monitor and analyse the } \\
\text { applications of novel } \\
\text { technologies and practices, } \\
\text { within Europe; it will merge } \\
\text { the characteristics of the } \\
\text { existing observatories and } \\
\text { European hubs with the aim to } \\
\text { be a reference in the } \\
\text { dissemination of knowledge } \\
\text { about SC and increase the } \\
\text { competitiveness of European } \\
\text { SC } \\
\text { Address the focus of the } \\
\text { European SC observatory on a } \\
\text { systemic perspective that } \\
\text { integrates business processes, } \\
\text { SC networks, and SC } \\
\text { technologies } \\
\text { Foster the deep analysis of the } \\
\text { European networks in order to } \\
\text { enable the benchmarking and } \\
\text { the cross sectorial sharing of } \\
\text { knowledge on last research } \\
\text { results and best practices } \\
\text { Monitor the future trends that } \\
\text { can have strong affect the } \\
\text { network performances, and } \\
\text { define the roadmaps and } \\
\text { research priorities for the } \\
\text { future SCs }\end{array}$ \\
\hline
\end{tabular}




\subsection{Establishing Infrastructure for Fostering of Future European SCs}

The traffic volume in cities increased significantly over the last decades. Between 2008 and 2035, population in the EU is expected to increase from about 500 million inhabitants to more than 521 million (Eurostat 2019). Therefore, Europe ranks among the most densely populated regions worldwide. As near to $80 \%$ of the EU-citizens live in cities and congestion in urban areas almost seems to be inevitable (Haon et al. 2015). Simultaneously, the diffusion of internet, smart phones and other technologies caused a massive growth of e-commerce. Moreover, an increasing number of retailers offers same-day delivery options. From a city logistics perspective, speedy deliveries to consumers' homes, rather than stores, multiply the number of freight movements and contribute intensely to the congestion and pollution of cities (Savelsbergh and van Woensel 2016).

To put it in numbers, urban areas freight transportation accounts for 10-15\% of vehicle equivalent miles, while being responsible for $25 \%$ of related $\mathrm{CO}_{2}$ emissions; $30-50 \%$ of other traffic related pollutants, like particulate matter or nitrogen oxide; and a significant part of the noise produced. These problems are fanned by very low load factors of delivery vehicles (e.g. 38\% for vans in London). Opposing these worrisome developments, EU legislation mandates zero $\mathrm{CO}_{2}$ emissions in cities by 2030 (Haon et al. 2015).

Transportation which does not use roads needs planning and construction of a whole new infrastructure within an existing city. Conceivable concepts like the Transit Elevated Bus-TEB in China or the Hyperloop planned for LA (underground) take time, impose enormous costs with a long investment horizon, need space and therefore might not be technically or economically feasible in many cities. As congestion and pollution in urban areas require solutions in the near term, already existing infrastructure should be used. To solve the above-mentioned issues effective adaptations, which facilitate the use of eco-friendly vehicles and innovative solutions for the delivery of the last mile, are essential. These instruments encompass the expansion of a charging infrastructure for e-vehicles of different types, the transnational harmonization of standards and regulations for low-emission zones and the transformation of open spaces into parcel centres or micro depots. The implementation of these remedies demonstrated to take less time, fewer financial resources and planning capacities than introducing a new infrastructure as an alternative to roads (e.g. a rail network) (Standing et al. 2019).

Moreover, in order to supply the last mile efficiently, logistics providers depend on relevant data. Therefore, three fundamental prerequisites should be met: first of all, a fully covered 5G-network is needed with a special focus on supply gaps in rural areas and small cities. Furthermore, useful data should be transmitted via open communication protocols and standards in order to prevent information from being kept secret. As an alternative and third requirement, local enterprises and municipalities are obliged to join and pool their data in a confidential and secure ITinfrastructure (Clausen et al. 2016). The development of a powerful $5 \mathrm{G}$ infrastructure 
is promising to result in a better linkage of different system entities and thus improved information sharing. The integrated collection and processing of real-time data from different sources allows for new mobility services and assisting functions improving route planning and flow of traffic (Lernende Systeme 2019).

While $5 \mathrm{G}$ brings significant benefits to already existing systems, its positive impact on sustainable urban logistics is even more tremendous when the future development of autonomous driving is considered. Self-driving vehicles are highly dependent on the low latency, reliability and velocity of the new radio technology (Hawkins and Habib 2019). As mobility-on-demand-services become more affordable with Autonomous Vehicles (AVs), many urbanites might be incentivized to use these sharing opportunities: studies show that shared services can be offered at a per-mile cost comparable to private vehicle ownership and are much cheaper than on-demand driver-operated transport (Bagloee et al. 2016). As a result, the number of cars and thereby congestion and parking requirements drop substantially (Beirigo et al. 2018). For instance, studies show that connected AVs perform two to three times better at intersections than traffic lights (Bagloee et al. 2016). Furthermore, Agatz et al. (2012) show that the "shareability"-rate of single-passenger rides in most urban centres worldwide is high yet unexplored.

To maximize the potentials of AVs, any provider of such services should opt for mixed-purpose fleets, i.e. vehicles equipped with parcel lockers to transport freight and passengers simultaneously. As far as economic reasons are concerned, studies indicate that the integration of people and cargo yields higher profits (Beirigo et al. 2018). Other than that, such AVs enhance the sustainability of urban logistics as they offer an excellent solution for affordable and convenient same-day and timewindow delivery requests. At night, they can be used as mobile pickup stations, while operation is also feasible on Sundays, further rectifying traffic and congestion (Joerss et al. 2016).

In general, many functionalities are feasible with the existing wireless technologies (like Bluetooth and WLAN) and infrastructure. Thus, promoting 5G and $\mathrm{AVs}$ is a less capital-intensive and time-consuming strategy compared to building a new infrastructure for the new radio technology. Table 7 presents the two policy recommendations on infrastructure.

\section{Conclusions}

Due to the rapidly changing environments that characterise contemporary society, the competitiveness of European SCs depends on a great variety of aspects, and demands the participation of a great number of actors. This chapter aimed to present a set of KHIs and recommendations that especially target European policy makers. KHIs impact both supply and demand side in the policy making as they set the framework for adoption (demand) and deployment (supply) (Exclude) of new actions for improving competitiveness of SCs. The 12 identified policy recommendations can be summarized in these macro-areas: assuring appropriate standards and legislation 
for European SCs; educating and training professionals for the future SCs; drafting of international agreements aiming at future European SCs; supporting and fostering incentives and funding schemes; promoting reference bodies for European SCs; and establishing infrastructure for fostering of future European SCs.

Based on research and on continuous communication with experts, the 12 recommendations represent a balanced set of suggestions that are broad and challenging, but are, at the same time, feasible in terms of implementation, with a coordinated action where private and public bodies work in a common direction. The formulation of these recommendations has considered also the core guidelines of the Horizon Europe. The new workprogramme was built around the vision of "a sustainable, fair and prosperous future for people and planet based on European values" and is aligned with the 17 sustainable development goals proposed by the United Nations. The main objectives of the programme can be described as: (i) to strengthen the EU's scientific and technological bases and the European Research Area (ERA); (ii) to boost Europe's innovation capacity, competitiveness and jobs; (iii) to deliver on citizens' priorities and sustain the socioeconomic model and values.

Table 7 Policy recommendations on infrastructure

\begin{tabular}{|c|c|c|}
\hline Policy recommendation & Main issue & What should policy makers do? \\
\hline $\begin{array}{l}\text { Upgrading infrastructures for } \\
\text { low-emission SCs }\end{array}$ & $\begin{array}{l}\text { Due to the volume of traffic, } \\
\text { cities are not only congested, } \\
\text { but polluted with hazardous } \\
\text { emissions and noise. Logistics } \\
\text { companies are required to } \\
\text { come up with a solution while } \\
\text { at the same time realizing } \\
\text { (same-day) deliveries on the } \\
\text { last mile }\end{array}$ & $\begin{array}{l}\text { Ensure that most vehicles, } \\
\text { use alternative, eco-friendly } \\
\text { drive technologies, the } \\
\text { charging infrastructure for } \\
\text { these fuels has to be } \\
\text { expanded significantly, both } \\
\text { for urban and intercity } \\
\text { logistics } \\
\text { - Main transport routes like } \\
\text { the trans-European core } \\
\text { network corridors (TEN-T) } \\
\text { should mainly be equipped } \\
\text { with stations for hydrogen. } \\
\text { This fuel outperforms } \\
\text { electricity at high speed, long } \\
\text { distance and heavy loads } \\
\text { Promote the conditioned } \\
\text { offering of conveniently } \\
\text { located open spaces. The } \\
\text { allocation of such areas } \\
\text { should be made dependent } \\
\text { on the obligation of the } \\
\text { logistics companies to use } \\
\text { low-emission and } \\
\text { noise-reduced vehicles } \\
\text { exclusively }\end{array}$ \\
\hline
\end{tabular}


Table 7 (continued)

\begin{tabular}{|c|c|c|}
\hline Policy recommendation & Main issue & What should policy makers do? \\
\hline $\begin{array}{l}\text { Promoting } 5 \mathrm{G} \text { and } \mathrm{AVs} \text { to } \\
\text { improve urban } \mathrm{SCs}\end{array}$ & $\begin{array}{l}\text { There is a need to improve } \\
\text { route planning and optimize } \\
\text { traffic flow. Real-time data } \\
\text { exchange is critical and helps } \\
\text { integrating logistics companies } \\
\text { and other important entities, } \\
\text { such as public infrastructure } \\
\text { operators, road maintenance, } \\
\text { construction companies and } \\
\text { cars }\end{array}$ & $\begin{array}{l}\text { - Accelerate the development, } \\
\text { implementation and diffusion } \\
\text { of the new radio technology } \\
\text { within logistics networks } \\
\text { - Enhance contribution of AVs } \\
\text { to smart and sustainable } \\
\text { logistics, less congestion and } \\
\text { pollution could be vast. } \\
\text { Potential barriers to the fast } \\
\text { development and } \\
\text { deployment of autonomous } \\
\text { driving include high initial } \\
\text { costs, AV certification, } \\
\text { liability and perception } \\
\text { issues, Cybersecurity, } \\
\text { privacy as well as missing } \\
\text { research efforts. European } \\
\text { policy makers are } \\
\text { recommended to make the } \\
\text { permission of broad public } \\
\text { usage of AVs a top priority } \\
\text { Foster a fast, secure and } \\
\text { reliable } 5 \mathrm{G} \text {-infrastructure } \\
\text { which allows for the required } \\
\text { data-exchange and } \\
\text { integration of different } \\
\text { system entities, like road } \\
\text { maintenance, mapping } \\
\text { companies and cars }\end{array}$ \\
\hline
\end{tabular}

An analysis of the fit of the policy recommendations to different aspects of the framework shows that the recommendations can significantly contribute to all the three pillars:

- Pillar 1-Excellent science. It aims at reinforcing and extending the excellence of Union's science base by means of the European Research Council, Marie Skłodowska-Curie Actions and the investments in world-class research infrastructures.

- Pillar 2-Global challenges and European industrial competitiveness. It aims at boosting key technologies and solutions underpinning EU policies \& Sustainable Development Goals as for example: digital industry and space, civil security for society, health, climate, energy and mobility;

- Pillar 3-Innovative Europe. It aims at stimulating market-creating breakthroughs and ecosystems conducive to innovation by means of European Innovation Council (EIC), European innovation ecosystems (connecting with national and regional actors), and European Institute of Innovation and Technology (EIT). 
Table 8 presents a summary of the policy recommendations, including the organisations to be involved in the implementation of the actions and the expected beneficiaries.

Table 8 Summary of the policy recommendations

\begin{tabular}{|c|c|c|c|}
\hline $\begin{array}{l}\text { Policy } \\
\text { recommendation }\end{array}$ & $\begin{array}{l}\text { Type of action and } \\
\text { Horizon Europe pillar }\end{array}$ & $\begin{array}{l}\text { Organisations } \\
\text { involved in the } \\
\text { implementation }\end{array}$ & Beneficiaries \\
\hline $\begin{array}{l}\text { Fostering } \\
\text { harmonisation of } \\
\text { legislation and } \\
\text { standards on European } \\
\text { SCs }\end{array}$ & $\begin{array}{l}\text { Policy } \\
\text { Pillars 1-3 }\end{array}$ & $\begin{array}{l}\text { EC, National } \\
\text { Governments, } \\
\text { Standards } \\
\text { Development } \\
\text { Organisations }\end{array}$ & $\begin{array}{l}\text { Research institutions, } \\
\text { industry associations, } \\
\text { innovation hubs, } \\
\text { companies, customers }\end{array}$ \\
\hline $\begin{array}{l}\text { Disseminating } \\
\text { standards among } \\
\text { European SC } \\
\text { stakeholders }\end{array}$ & $\begin{array}{l}\text { Programme } \\
\text { Pillars 2-3 }\end{array}$ & $\begin{array}{l}\text { EC, Standards } \\
\text { Development } \\
\text { Organisations }\end{array}$ & $\begin{array}{l}\text { Research institutions, } \\
\text { industry associations, } \\
\text { innovation hubs, } \\
\text { companies }\end{array}$ \\
\hline $\begin{array}{l}\text { Facilitating and } \\
\text { boosting multimodal } \\
\text { transportation }\end{array}$ & $\begin{array}{l}\text { Project } \\
\text { Pillars 2-3 }\end{array}$ & $\begin{array}{l}\text { EC, National } \\
\text { Governments }\end{array}$ & $\begin{array}{l}\text { Industry/transport } \\
\text { associations, } \\
\text { companies, customers }\end{array}$ \\
\hline $\begin{array}{l}\text { Developing the } \\
\text { workforce for the SCs } \\
\text { of the future }\end{array}$ & $\begin{array}{l}\text { Policy } \\
\text { Pillars 1-2-3 }\end{array}$ & $\begin{array}{l}\text { EC, Research \& } \\
\text { education institutions, } \\
\text { National } \\
\text { Governments, SC } \\
\text { associations, } \\
\text { companies }\end{array}$ & $\begin{array}{l}\text { Education institutions, } \\
\text { SC professionals, } \\
\text { companies }\end{array}$ \\
\hline $\begin{array}{l}\text { Promoting bi- and } \\
\text { multi-lateral } \\
\text { agreements that } \\
\text { consider an overall SC } \\
\text { perspective }\end{array}$ & $\begin{array}{l}\text { Policy } \\
\text { Pillar } 2\end{array}$ & $\begin{array}{l}\text { EC, National \& } \\
\text { International } \\
\text { Governments, SC } \\
\text { associations }\end{array}$ & $\begin{array}{l}\text { Companies, SC } \\
\text { associations }\end{array}$ \\
\hline $\begin{array}{l}\text { Supporting the } \\
\text { establishment of R\&D } \\
\text { networks for } \\
\text { advancements and } \\
\text { dissemination of } \\
\text { SC-related topics }\end{array}$ & $\begin{array}{l}\text { Policy } \\
\text { Pillars 1-3 }\end{array}$ & $\begin{array}{l}\text { EC, Research } \\
\text { institutions, National } \\
\text { \& International } \\
\text { Governments, SC } \\
\text { associations }\end{array}$ & $\begin{array}{l}\text { Research \& education } \\
\text { institutions, } \\
\text { companies, SC } \\
\text { associations }\end{array}$ \\
\hline $\begin{array}{l}\text { Enhancing } \\
\text { collaboration based on } \\
\text { European Projects } \\
\text { results: creation of a } \\
\text { platform for data } \\
\text { repository }\end{array}$ & $\begin{array}{l}\text { Project } \\
\text { Pillar } 1\end{array}$ & $\begin{array}{l}\text { EC-DGs, Research } \\
\text { institutions. }\end{array}$ & $\begin{array}{l}\text { EC, research } \\
\text { institutions, } \\
\text { companies }\end{array}$ \\
\hline $\begin{array}{l}\text { Establishing a Prize to } \\
\text { support and spread } \\
\text { best practices in the } \\
\text { SC }\end{array}$ & $\begin{array}{l}\text { Programme } \\
\text { Pillars 2-3 }\end{array}$ & $\begin{array}{l}\text { EC-DGs, Research } \\
\text { institutions, SC } \\
\text { associations, } \\
\text { companies. }\end{array}$ & $\begin{array}{l}\text { Companies, SC } \\
\text { associations, SC } \\
\text { professionals, research } \\
\text { institutions }\end{array}$ \\
\hline
\end{tabular}


Table 8 (continued)

\begin{tabular}{l|l|l|l}
\hline $\begin{array}{l}\text { Policy } \\
\text { recommendation }\end{array}$ & $\begin{array}{l}\text { Type of action and } \\
\text { Horizon Europe pillar }\end{array}$ & $\begin{array}{l}\text { Organisations } \\
\text { involved in the } \\
\text { implementation }\end{array}$ & Beneficiaries \\
\hline $\begin{array}{l}\text { Creating synergies } \\
\text { between public and } \\
\text { private sectors in } \\
\text { funding }\end{array}$ & $\begin{array}{l}\text { Project } \\
\text { Pillar 2 }\end{array}$ & $\begin{array}{l}\text { EC, National } \\
\text { Governments, } \\
\text { Companies }\end{array}$ & $\begin{array}{l}\text { SC associations, } \\
\text { companies, national } \\
\text { governments, research } \\
\text { institutions, innovation } \\
\text { hubs/clusters }\end{array}$ \\
\hline $\begin{array}{l}\text { Creating a European } \\
\text { SC knowledge hub for } \\
\text { sustainable, resilient } \\
\text { and inclusive SCs }\end{array}$ & $\begin{array}{l}\text { Project } \\
\text { Pillars 1-2-3 }\end{array}$ & $\begin{array}{l}\text { EC-DGs, National } \\
\text { Governments, } \\
\text { Research Institutions, } \\
\text { innovation hubs }\end{array}$ & $\begin{array}{l}\text { EC, national } \\
\text { governments, research } \\
\text { \& education } \\
\text { institutions, SC } \\
\text { associations, } \\
\text { companies, SC } \\
\text { professionals, } \\
\text { innovation } \\
\text { hubs/clusters }\end{array}$ \\
\hline $\begin{array}{l}\text { Upgrading } \\
\text { infrastructures for } \\
\text { low-emission supply } \\
\text { chains }\end{array}$ & $\begin{array}{l}\text { Programme } \\
\text { Pillars 2-3 }\end{array}$ & $\begin{array}{l}\text { EC, National } \\
\text { Governments, } \\
\text { Research institutions, } \\
\text { Companies }\end{array}$ & $\begin{array}{l}\text { National governments, } \\
\text { companies, customers }\end{array}$ \\
$\begin{array}{l}\text { autonomous vehicles } \\
\text { AVs) to improve } \\
\text { urban supply chains }\end{array}$ & $\begin{array}{l}\text { Programme } \\
\text { Pillars 1-2-3 }\end{array}$ & $\begin{array}{l}\text { EC, National } \\
\text { Governments, } \\
\text { Research Institutions, } \\
\text { Companies }\end{array}$ & $\begin{array}{l}\text { National governments, } \\
\text { companies, SC } \\
\text { associations, } \\
\text { customers }\end{array}$ \\
\hline
\end{tabular}

Acknowledgements We are grateful to all contributors of the Next-Net project team and particularly to Patrícia Gonçalves, Markus Stute, Sébastien Balech, Cemre Mutlu, Alicia Martinez de Yuso, Carolina Cipres, and Mustafa Çagri Gürbüz. This work was financially supported by the European Union's Horizon 2020 Research and Innovation Program under the Grant Agreement No. 768884 for the project NEXT-NET: Next generation Technologies for networked Europe.

\section{References}

Agatz N, Erera A, Savelsbergh M, Wang X (2012) Optimization for dynamic ride-sharing: a review. Eur J Oper Res 223(2):295-303

American Production and Inventory Control Society (APICS) (2019) Available at: http://www. apics.org/

Bagloee SA, Tavana M, Asadi M, Oliver T (2016) Autonomous vehicles: challenges, opportunities, and future implications for transportation policies. J Mod Transp 24(4):284-303

Beirigo BA, Schulte F, Negenborn RR (2018) Integrating people and freight transportation using shared autonomous vehicles with compartments. IFAC-PapersOnLine 51(9):392-397

Ben-Ner A, Siemsen E (2017) Decentralization and localization of production: the organizational and economic consequences of additive manufacturing (3D printing). Calif Manag Rev 59(2):523. https://doi.org/10.1177/0008125617695284 
Calatayud A, Mangan J, Christopher M(2018) The self-thinking supply chain. Supply Chain Manag: Int J 24(1):22-38

Clausen U, Stütz S, Bernsmann A, Heinrichmeyer H (2016) ZF-Zukunftsstudie. Die letzte Meile. Hg. v. ZF Friedrichshain AG. Fraunhofer IML

Committee for European Construction Equipment (CECE) (2019) Available at: https://www. cece.eu/home. Ecommerce Europe (2019) European ecommerce report 2019. Available at: https://www.ecommerce-europe.eu/wp-content/uploads/2019/07/European _Ecommerce _ report_2019_freeFinal-version.pdf

Copeland E (2017) How to write policy recommendations that influence government. Available at: http://eddiecopeland.me/how-to-write-recommendations-that-change-government-policy/

Doyle S (2017) Writing for government and the public sector. Available at: https://web.uvic.ca/ sdo yle/E302/index.html

Project Erasmus+: NIFORZS-Universities for future work skills 2020 (2019) Available at: https:// www.fit4fof.eu/catalogue/project-erasmus-uniforzs-universities-for-future-work-skills-2020

European Commission (2018a) EU budget for the future-horizon Europe: EU funding for research and innovation 2021-2027. Available at: https://ec.europa.eu/commission/sites/beta-political/ files/budget-may2018-research-innovation_en.pdf

European Commission (2018b) 2018 - year of multimodality. Available at: https://ec.europa.eu/tra nsport/themes/logistics-and-multimodal-transport/2018-year-multimodality_en

European Commission (2019a) https://ec.europa.eu/info/news/commission-launches-work-majorresearch-and-innovation-missions-cancer-climate-oceans-and-soil-2019-jul-04_en

European Commission (2019b) Free movement in harmonised and non-harmonised sectors. Available at: https://ec.europa.eu/growth/single-market/goods/free-movement-sectors_en

European Commission (2019c) Regional regulatory harmonisation. Available at: https://ec.europa. eu/europeaid/regional-regulatory-harmonisation_en

European Commission (2019e) Skills and qualifications. Available at: https://ec.europa.eu/social/ main.jsp?catId=1146\&langId=en

European Environment Agency (2019a) Transport in Europe: key facts and trends. Available at: https://www.eea.europa.eu/signals/signals-2016/articles/transport-in-europe-key-facts-trends

Eurostat (2019) Maritime transport statistics—short sea shipping of goods. Available at: https://ec.europa.eu/eurostat/statistics-explained/index.php/Maritime_transport_statistics_-_ short_sea_shipping_of_goods\#Total_short_sea_shipping

Fornasiero R, Marchiori I, Pessot E, Zangiacomi A, Sardesai S, Barros AC, Thanous E, Weerdmeester R, Muerza V (2020) Paths to innovation in supply chains: the landscape of future research. In: Fornasiero et al (eds) Next generation supply chains: a roadmap for research and innovation. Springer, Cham

Fratini CF, Georg S, Jorgensen MS (2019) Exploring circular economy imaginaries in European cities: a research agenda for the governance of urban sustainability transitions. J Clean Prod 228:974-989

Fugate B, Pagell M, Flynn B (2019) From the editors: introduction to the emerging discourse incubator on the topic of research at the intersection of supply chain management and public policy and government regulation. J Supply Chain Manag 55(2):3-5

Haon S, Monzon A, Berger A, Caux D, Liesa F, Lu M et al (2015) Urban freight. Research \& innovation roadmap. Hg. v. alice und Ertrac. Available at: http://www.etp-logistics.eu/wp-con tent/uploads/2015/08/W56mayo-kopie.pdf

Hawkins J, Habib KN (2019) Integrated models of land use and transportation for the autonomous vehicle revolution. Transp Rev 39(1):66-83

Joerss M, Schröder J, Neuhaus F, Klink C, Mann F (2016) Parcel delivery. The future of last mile. Hg. v. McKinsey\&Company. Available at: https://www.mckinsey.com/de/ /media/McK insey/Locations/Europe\%20and\%20Middle\%20East/Deutschland/News/Presse/2016/2016-0909/2016_the_future_of_last_mile.ashx

Lernende Systeme-Die Plattform für Künstliche Intelligenz (Hg) (2019) Auf dem Weg zu einem intelligenten Mobilitätsraum. Handlungsfelder, Chancen und Herausforderungen 
Lu Y, Morris KC, Frechette S (2016) Current standards landscape for smart manufacturing systems. Natl Inst Stand Technol NISTIR 8107:39

Min S, Zacharia ZG, Smith CD (2019) Defining supply chain management: in the past, present, and future. J Bus Logist 40:44-55

Morgan G (2017) Theory and practice in policy analysis-including applications in science and technology. https://doi.org/10.1017/9781316882665

Nakatomi (2012) Concept paper for an International Supply Chain Agreement (ISCA). Improving global supply chains by an issues-based plurilateral approach. Research Institute for Economy, Trade and Industry

Organisation for Economic Co-operation and Development (OECD) (2019) Policy briefs by topic. Available at: https://www.oecd.org/policy-briefs/bytopic/

Raustiala K (2005) Form and substance in international agreements. Am J Int Law 99(3):581-614

Savelsbergh M, van Woensel T (2016) City logistics: challenges and opportunities. Transp Sci 50(2):579-590

Stachova K, Papula J, Stacho Z, Kohnova L (2019) External partnerships in employee education and development as the key to facing industry 4.0 challenges. Sustainability $11(2): 1-19$

Standing C, Standing S, Biermann S (2019) The implications of the sharing economy for transport. Transp Rev 39(2):226-242

Szücs F (2020) Do research subsidies crowd out private R\&D of large firms? Evidence from European Framework Programmes. Res Policy 49(3):103923

Tokar T, Swink M (2019) Public policy and Supply Chain Management: using shared foundational principles to improve formulation, implementation, and evaluation. J Supply Chain Manag 55(2):68-79

Wieland A, Handfield RB, Durach CF (2016) Mapping the landscape of future research themes in supply chain management. J Bus Logist 37(3):205-212

Zimmermann R, Ferreira LMD, Moreira AC (2019) Strategic fit between innovation strategies and supply chain strategies: a conceptual study. Int J Value Chain Manag 10(3):258-273

Zimmermann R, Ferreira LMD, Moreira AC (2020) An empirical analysis of the relationship between supply chain strategies, product characteristics, environmental uncertainty and performance. Supply Chain Manag: Int J 25(3):375-391

Open Access This chapter is licensed under the terms of the Creative Commons Attribution 4.0 International License (http://creativecommons.org/licenses/by/4.0/), which permits use, sharing, adaptation, distribution and reproduction in any medium or format, as long as you give appropriate credit to the original author(s) and the source, provide a link to the Creative Commons license and indicate if changes were made.

The images or other third party material in this chapter are included in the chapter's Creative Commons license, unless indicated otherwise in a credit line to the material. If material is not included in the chapter's Creative Commons license and your intended use is not permitted by statutory regulation or exceeds the permitted use, you will need to obtain permission directly from the copyright holder.

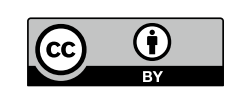

